https://doi.org/10.18485/bogoljub_stankovic.2018.ch12

811.163.41'367.622

811.162.3'367.622

811.163.41:811.162.3

КАТАРИНА МИТРИЋЕВИЋ-ШТЕПАНЕК*

Универзитет у Београду

Филолошки факултет

Катедра за славистику

\title{
ФОРМАЛНИ ДЕМИНУТИВИ У ЧЕШКОМ ЈЕЗИКУ И ЊИХОВИ ПРЕВОДНИ ЕКВИВАЛЕНТИ У ДВОЈЕЗИЧНОМ ЧЕШКО-СРПСКОМ РЕЧНИКУ
}

Рад се бави деминутивним изведеницама чија је форма употребљена за именовање недеминутивног појма на основу преноса инваријантног значења у процесу лексикализације. Анализира се форма и семантика тих деривата у чешком језику, те њихових еквивалената у српском језику и скреће пажња на њихову обраду у оквиру речничке одреднице у двојезичном чешко-српском речнику у поређењу са стањем у једнојезичним речницима чешког и српског језика.

Клучне речи: формални деминутив, лексикализација, чешки језик, српски језик, еквиваленција, двојезични речник, лексикографска обрада

Katarina Mitrićević-Štepanek

\section{LEXICALIZED DIMINUTIVES IN THE CZECH LANGUAGE AND THEIR LEXICOGRAPHICAL EQUIVALENTS IN BILINGUAL CZECH-SERBIAN DICTIONARY}

The paper deals with diminutive derivatives with lexicalized meaning. The form and semantics of these derivatives in the Czech language and their lexicographical equivalents in the Serbian language are analysed based on entries in monolingual dictionaries of Czech and Serbian and bilingual Czech-Serbian dictionary.

Keywords: lexicalized diminutives, lexicalization, Czech language, Serbian language, equivalence, bilingual dictionary, lexicographical treatment of entries

Однос и значај конфронтативног и лексикографског сучељавања два језика истакао је професор Богољуб Станковић речима: „Имајући у виgу gа је gвојезични речник најексйлиийније конфронйаиионо сайлеgавање

\footnotetext{
*k.mitricevic@fil.bg.ac.rs
} 
и ирреgстиављање чињенииа gвају језика, сасвим ирирояно би било gа се у нашим буяућим аніанованима на слависиичком йољу комитлеменитарно иовезују конфронйационе срйско-инословенске анализе и лексикоірафско сучељавање срйской са остиалим словенским језицима." (Станковић 1999: 131). Ми у нашем конфронтативном истраживању посвећујемо пажњу формалним деминутивима у чешком и српском језику који према укључивању у процес лексикализације представљају изазов како у једнојезичној, тако и двојезичној лексикографији.

Деминутиви примарно означавају појам који је мањи од нормалне, уобичајнене величине и у том случају ради се о правом деминутивном значењу, потом могу да означавају појам према ком говорник изражава субјективни став, већином позитиван али и негативан, и то је експресивно, или хипокористично значење. Као треће ови деривати могу имати формално деминутивно значење које се испољава кроз процес лексикализације (или специјализације) и у том случају деминутиви означавају самостални појам који нема ни деминутивно ни емотивно обојено значење. ${ }^{1}$ Ове изведенице постају полисемичне лексеме које задржавају, или пак сасвим губе, своје примарно деминутивно значење, развијајући једну или више секундарних семантичких реализација.

На ове језичке јединице осврћу се граматике и приручници чешког језика, обрађујући творбену и семантичку страну деминутива. В. Шмилауер (Šmilauer 1971) у оквиру деминутива овог типа разликује специјализацију (mozeček, plavčík, čárka, poutko), померање значења (večírek, lahůdka, olůvko), пренос значења - метафору (jazýček, kohoutek, muška, očko). Akademická gramatika spisovné češtiny такође се осврће на овај тип деминутива, и то у оквиру две функције - номинационе функције деминутива која се састоји у томе да је „deminutivní forma... prostředkem utvoření nového slova pojmenovávajícího dosud nepojmenovaný objekt; obvykle pritom jde o lexikální metafory: banán $\rightarrow$ banánek, bomba $\rightarrow$ bombička, rameno $\rightarrow$ ramínko (na šaty)" и функције која комбинује деминуцију и номинацију самосталне врсте предмета, наводећи примере „lopata (velká, na uhlí) $\rightarrow$ lopatka (malá, na smetí), láhev (velká, pivní) $\rightarrow$ lahvička (malá, s léky, parfémem; flakon), chlév (velký, pro krávy) $\rightarrow$ chlívek (malý, pro prase, kozu)" и др. (Štícha et al. 2013: 154). Детаљније им се посвећују истраживачи у појединачним радовима. На пример, Ф. Штиха (Štícha 1978) проучава одсуство њиховог деминутивног обележја, класификује их према критеријуму типа лексикализације, врсте семантичког померања и мотивације за употребу деминутив-

${ }^{1}$ У енциклопедијском речнику наводи се да је лексикализација „pretvaranje nekog leksičkog elementa... u jedan kompaktni jezički elemenat koji ima funkciju zasebne reči" (Ресо et al. 1972: 200). Специјализацију значења пак енциклопедијски речник чешког језика (Nový encyklopedický slovník češtiny) дефнише као сужавање обима значења ширењем његовог садржаја, тј. повећањем његових конститутивних сема (Karlík et al. 2016: 577). 
не форме, и утврђује пет типова лексикализованих деминутива наводећи бројне примере: тип knížka - не ради се о семантичком померању или специјализацији, већ и деминутивни и недеминутивни облик означавају исти денотат (hříbek, zornička, svíčka, miminko, vajíčko); тип slovíčko - значење деминутива се разликује од мотивне речи само по специјалној конотацији (stupínek, mozeček, dárek, novinka, lavička, ledvinky, stř́vko); тип lopatka - именују се знатно мањи предмети од оних који су именовани мотивном речи, али су свакако засебни и њихов мањи обим је стандардан (balónek, žlábek, pytlík, bombička, hadička, hodinky, sklenička, zrcátko); тип banánek - ради се о посебоој деноминацији насталој на основу метафоричног и метонимијског преноса значења (bubínek, kočárek, čepička, hvězdička, dušičky, víčko, kolečko); тип sýček - у ботаници и зоологији су употребљени деминутивни облици за именовање животињских и биљних врста које имају већи број сличних карактеристика са другим врстама (orlík, lvíček, myška, ředkvička). Аутор формалне деминутиве дефинише на следећи начин: „Substantiva deminutivní formy s lexikalizovaným významem označujeme taková deminutiva: a) jejichž primární a jedinou funkcí není vyjadřovat menší míru (velikost, váhu) některého předmětu... b) jejichž primární vyjadřovací funkcí není príznak expresívnosti či (citového) hodnocení" (Исто: 118). 3. Хлатка истражује њихову примену код грађења народних назива биљака дефинишући да је то тип формалних или лексикализованих деминутива код којих се ради о тиме да „...významový vztah mezi základním slovem a formálním deminutivem má pouze motivační funkci. Formální deminutivum vzniká na základè podobnostní (souvislostní) relace mezi pojmenovávanou a motivující skutečností a lexikalizuje se ve významu podstatně odlišném od sémantiky slova výchozího" (Hladká 1998: 108).

Формални деминутиви у чешком језику проучавани су и конфронтативно, нпр. Г. Бакарџијева (Bakardžieva 2007) у оквиру анализе семантике деминутива помиње и оне који су „подлегли лексикализацији”, наводећи примере у бугарском и чешком и поредећи ову појаву у оба језика. Она такође истиче да је степен осамостаљења тих деривата могуће утврдити између осталог провером да ли се лексеме наводе као самосталне секундарне семантичке реализације у описним и преводним речницима.

У српском језику о формалним деминутивима говори у свом приручнику о творби речи И. Клајн, истичући да је деминуција „иестио gовела и gо секундарної йомерања значења" уз примере као што су нпр. јеленак, редак, братић, кошуљица (2003: 26, 51, 109, 115). ${ }^{2}$ И М. Стевановић

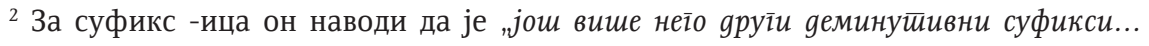

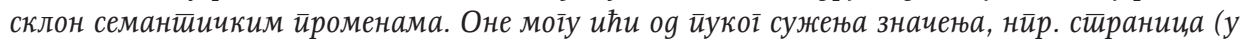

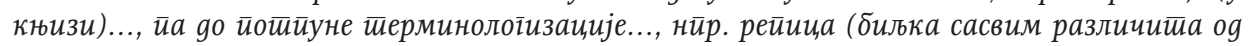


осврће се на деминутиве грађене суфиксом -ица који се употребљавају и у „служби їgе је ово значење ослабило или се савим изіуубило. То је, йре

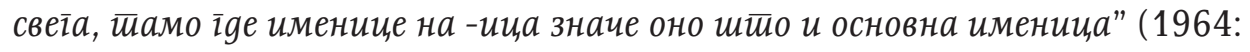
551). Он наводи примере као главица, ручица, вуница „с иромењеним акиентиом није вуна, нето у фабрии, израђен вунени конаи, за йлейење", јабучица и друге, а одмах затим пише да је велики број именица које

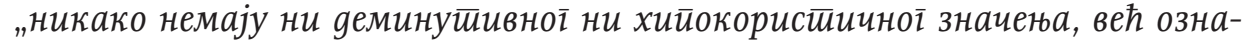

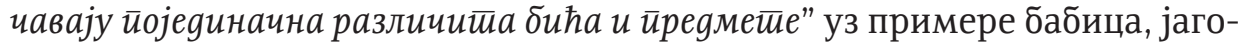
дица, капица, корица, лопатица, погачица, постељица и сл. (Исто: 552). У појединачним радовима о овим дериватима пише нпр. И. Грицкат објашњава лексикализацију као „бежање оg обележавања умањеностии”,

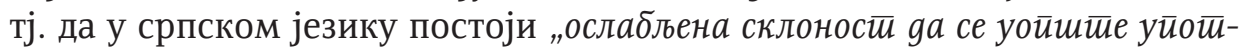
ребљавају уколико није найлашена йотиреба за юима, ијј. за юиховом основном службом, йа су с тиим у вези деминуирани именички облии, временом сииицали а и саgа стииу нова значења, они се, gакле, лексикализују" (1995: 7). Наведену појаву ауторка илуструје између осталих и изведеницама са суфиксима -(ч)ак, -(ч)ић и -(ч)ица уз бројне примере, као нпр. узорак, кутак, чланак, бисерак, јеленак, котлић, коњић, каранфилић, жабица, кобилица, мерица, гумица, књижица, тиквица итд. (Исто : 8, 9). П. Радић (1997) обраћа пажњу на творбено-семантички механизам морфонолошке алтернације к/ч код деминутива (рукица/ручица, ногица/ ножица), сматрајући да се облик без алтернације појављује управо као средство деминуције, због тога што се облик са алтернацијом све више осећа као лексикализован, те да се њено активирање или неактивирање јавља као семантички дистинктивни елемент. О значењима изведенице ручица говори Р. Драгићевић (2008), сматрајући да је њено предметно значење пореклом од деминутивног, те да је досадашња лексикографска пракса по којој се деминутивно и предметно значење обрађују у оквиру исте полисемантичке структуре сасвим исправна. Ауторка даље одређује значење лексеме ручица у односу на њене сродне деривате - рукица и ручка и закључује да је облик ручица много распрострањенији у деминутивном значењу у односу на изведеницу рукица, што значи да деминутивно значење ту доминира над предметним. Н. Бечева (2000) такође упозорава на зависност између деминутивних суфикса и значења, посебно када се ради о дублетима са и без палатализације, као и на ослабљивање деминутивности и лексикализацију деминутива. А. Јанић (2012) бави се лексикализованим деминутивима у целини, објашњавајући појаву лексикализације именичких деминутива са лексиколошког, творбеног и семантичког аспекта. Ауторка одређује најважније

рейe)...", уз бројне примере као нпр. девојчица, госпођица, марамица, водица, звездица и друге. (Клајн 2003: 115). 
критеријуме за идентификацију лексикализованих деминутива, у које спадају деривираност речи, механизам метафоре, полисемичност одреднице у речнику, семантичке модификације, полисемичност термина, (углавном) кратак акценат на првом слогу, као и преводни еквиваленти на енглески и руски језик, те на основу датих критеријума издваја око четрдесет лексикализација, као нпр. језичак, каранфилић, вртић, бабица, јагодица, марамица, бубица, свећица, окце и др. У другом раду ауторка дели лексикализиване деминутиве у три групе - деминутиви постоје као термини у одређеној науци/дисциплини (бабица, чепић); деминутиви се употребљавају у одређеној области или занату (погачица, стрелица); делимично, слабо лексикализовани деминутиви чије је значење у метафоричној вези са умањеним предметом који је у основи деминутива, али се деминутивност још увек осећа (књижица, братић, пахуљице), а пажњу посвећује пореклу основе лексикализованих деминутива, суфиксима којима су изведени, значењу лексикализација и степену лексикализованости (Јанић 2013).

Лексикализовани деминутиви предмет су интересовања и у оквиру конфронтативних истраживања српског и других словенских језика. На пример, П. Легурска и Н. Бечева (Легурска 2000) анализирају значења деминутива у руском, српском и бугарском језику који означавају делове тела према томе како су представљени у двојезичним речницима, узимајући у обзир и лексикализоване деминутиве, закључујући да је од посебне важности да аутори двојезичних речника разграниче случајеве када је дошло до потпуне лексикализације код које изведеница означава потпуно нов денотат, а када она још увек задржава и деминутивно значење. Бавећи се питањима међујезичке еквиваленције на примеру деминутива у руском и српском језику, Ј. Матијашевић говори између осталог и о способности ширења њиховог значења у сферу ван деминуције, те да је у руском и српском језику веома широк круг назива добијених семантичком деривацијом од деминутива, односно метафором и метонимијом, али да „сваки има своја лексичка решења за реалије из об-

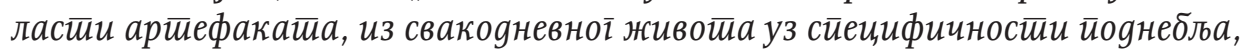
исхране, фитионима, зоонима и сл. йа је и еквивалениија у склаяу с иим" (2012: 657).

За потребе нашег истраживања ми смо користили једнојезичне дескриптивне речнике чешког и српског језика, и то Slovník spisovného jazyka českého (Havránek et al. 1960-1971), даље SSJČ, и Речнuк срӣскох-

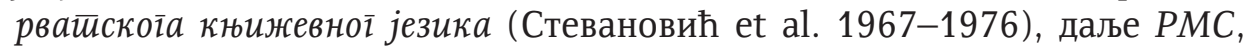
те двојезични Чешко-срйски речник (Качаник et al. 2001), даље ЧСР. Пажњу смо посветили оним лексемама у чешком језику које су развиле секундарне семантичке реализације, али које још увек, као основно, инваријантно значење задржавају семантику деминутивности наведену 
у речнику SSJČ под бројем 1 и означене квалификатором „zdrob. $k^{\prime \prime}{ }^{3}$ Затим смо утврдили преводне еквиваленте у речнику ЧСР, а на основу речника $P M C$ упоредили и прецизирали њихова значења и понудили могуће допуне, уз појашњења и прецизирања преводне еквиваленције.

На основу анализе грађе издвојили смо главне типове еквиваленције, а то су:

а. Формалном деминутиву у чешком језику одговара формални деминутив у српском језику. Он може обухватати све семеме полисемичног деминутива у чешком језику које су наведене у речнику SSJČ, или већину њих.

\begin{tabular}{|c|c|c|}
\hline SSJČ & ЧСР & $\mathrm{PMC}$ \\
\hline $\begin{array}{l}\text { aršík } \\
\text { 1. zdrob. k arch } \\
\text { 2. filat. list s natištěnou } \\
\text { známkou n. kombinací } \\
\text { známek }\end{array}$ & $\begin{array}{l}\text { мали табак, арак (1) } \\
\text { табачић, листић }(2)^{4}\end{array}$ & $\begin{array}{l}\bar{u} а \delta а ч и ћ \\
\text { дем. од табак }\end{array}$ \\
\hline $\begin{array}{l}\text { bradka } \\
\text { 1. zdrob. k brada } \\
\text { 2. vousy na bradě }\end{array}$ & $\begin{array}{l}\text { 1. анат. брадица, брада } \\
\text { (део лица) } \\
\text { 2. брада (длаке на бради })^{5}\end{array}$ & $\begin{array}{l}\text { браguиа } \\
\text { дем. од брада }\end{array}$ \\
\hline
\end{tabular}

${ }^{3}$ Речничку одредницу у табелама примера скраћујемо и наводимо само оне елементе који се тичу наше анализе, такође испуштамо нека од слабије фреквентних значења због уштеде простора. Фонд деминутива није ексцерпиран у потпуности, већ искључиво по нашем избору, како би што прецизније илустровао формалну и семантичку страну процеса лексикализације.

${ }^{4}$ Аутори речника ЧСЈ наводе између осталих и речник SSJČ, али избор речи и њихова обрада обухвата и другу бројну литературу, тако да се структура одредничког одељка унеколико разликује. У неким случајевима еквиваленција приказује само специјализацију, не и лексикализацију значења, како је наведено у чешком речнику. Уколико је дошло до разилажења а како би било јасно на које семеме чешке лексеме се преводни еквиваленти односе стављали смо иза њих у загради бројеве који одговарају значењима деминутива у чешком језику.

${ }^{5}$ У неким случајевима решење аутора ЧСР је да као преводни еквивалент употребе мотивну реч а не деминутив, мада се он, по нашем мишљењу, користи у датом значењу, као код овог примера. 


\begin{tabular}{|c|c|c|}
\hline $\begin{array}{l}\text { čepička } \\
\text { 1. zdrob k čepice } \\
\text { 2. bot. pletivo chránící } \\
\text { špičku kořene } \\
\text { 3. techn. menší ochranný } \\
\text { kryt: č. ventilu }\end{array}$ & $\begin{array}{l}\text { 1. капица, капа } \\
\text { 2. бот. коренова капица } \\
\text { (3) (није наведено })^{6}\end{array}$ & $\begin{array}{l}\text { кайиц, } \\
\text { 1. дем. од капа } \\
\text { 2. комадић коже који се } \\
\text { пришива на врх предњег } \\
\text { дела ципеле или опанка } \\
\text { с горње стране } \\
\text {.. } \\
\text { 4. мн. зоол. врста јести- } \\
\text { вих шкољака }\end{array}$ \\
\hline $\begin{array}{l}\text { domek } \\
\text { 1. zdrob. k dům } \\
\text { 2. ulita plžů }\end{array}$ & $\begin{array}{l}\text { 1. кућица, мала кућа, } \\
\text { кућа } \\
\text { 2. пужева кућица }\end{array}$ & $\begin{array}{l}\text { кућuи, } \\
\text { 1. дем. од кућа } \\
\text { 2. тврди заштитни пок- } \\
\text { ров пужа у облику спи- } \\
\text { ралне и овалне шкољке }\end{array}$ \\
\hline $\begin{array}{l}\text { hlavička } \\
\text { 1. zdrob. k hlava } \\
\text {... } \\
\text { 3. věc tvarem (popř. polo- } \\
\text { hou) připomínající malou } \\
\text { hlavu, podobná malé hlavě: } \\
\text { h. zelí; h. notová } \\
\text { 4. rozšírené zakončení } \\
\text { něčeho: h. zápalky, špen- } \\
\text { dlíku } \\
\text { 5. horní část písemností n. } \\
\text { tiskovin; záhlaví, nadpis }\end{array}$ & $\begin{array}{l}\text { 1. главица, глава } \\
\text { 2. наслов, натпис, заглавље } \\
(5) \\
\ldots \\
\Delta \text { муз. нотна глава }(3) ; \\
\text { глава чиоде }(4)^{7}\end{array}$ & $\begin{array}{l}\text { илавии, } \\
\text { 1. дем. и хип. од глава } \\
\text { 2. заокругљени део неких } \\
\text { биљака (лука, купуса) и } \\
\text { разних предмета (чиоде, } \\
\text { чавла, ексера итд.) }\end{array}$ \\
\hline $\begin{array}{l}\text { jablíčko } \\
\text { 1. zdrob k jablko } \\
\text { 2. věc připomínající nějak } \\
\text { (zprav. kulatým tvarem) } \\
\text { jablíčko }\end{array}$ & јабучица, јабука & $\begin{array}{l}\text { јабучии, } \\
\text { 1. дем. од јабука } \\
\text { 2. а. анат. избочена хрс- } \\
\text { кашца у грлу над улазом } \\
\text { у душник код мушкар- } \\
\text { ца; б. (обично мн.) в. ја- } \\
\text { годица; в. заобљени део } \\
\text { прста с унутрашње стра- } \\
\text { не, насупрот нокту, вр- } \\
\text { шак прста; г. очна кугла } \\
\text { коју творе бјелоочница } \\
\text { и рожњача; д. одебљали } \\
\text { део на крају кости, који } \\
\text { се у зглобовима углаба у } \\
\text { другу кост }\end{array}$ \\
\hline
\end{tabular}

${ }^{6}$ Ово значење није наведено у ЧСР, али сматрамо да се формални деминутив у српском језику користи и у том значењу, нпр. капица вентила.

${ }^{7}$ Како наводи PMC и облик илавиน, одговарао би семемама под 3 и 4 у SSJČ. 


\begin{tabular}{|c|c|c|}
\hline $\begin{array}{l}\text { klobouček } \\
\text { 1. malý klobouk } \\
\text { 2. věc menších rozměrů } \\
\text { něčím připomínající klo- } \\
\text { bouk, často něco uzavíra- } \\
\text { jící: k. hříbku, k tuby }\end{array}$ & $\begin{array}{l}\text { 1. шеширић, шешир; } \\
\text { 2. клобук (гљиве) }{ }^{8}\end{array}$ & $\begin{array}{l}\text { шеширић } \\
\text { 1. дем. од шешир } \\
\text { 2. врста колачића }\end{array}$ \\
\hline $\begin{array}{l}\text { kalíšek } \\
\text { 1. sklenička na likéry } \\
\text { 2. malá nádobka podoba- } \\
\text { jící se kalichu: k. na vejce } \\
\text { 3. bot. vnější obal květ- } \\
\text { ní listeny vyrůstajícími } \\
\text { zpod kalicha }\end{array}$ & $\begin{array}{l}\text { 1. чашица, чаша (за ра- } \\
\text { кију, вино); } \\
\text { 2. бот. цветна чашица ( } 3 \text { ) }\end{array}$ & $\begin{array}{l}\text { чашица } \\
\text { 1. дем. од чаша } \\
\text { 2. изолатор (обично } \\
\text { порцулански) на елек- } \\
\text { тричном уређају преко } \\
\text { којег се води жица } \\
\text { 3. анат. а. покретна ок- } \\
\text { ругла кост у колену, на } \\
\text { предњој страни коле- } \\
\text { ног зглоба...; } \\
\text { 4. бот. заштитни део } \\
\text { цвета, цветни омотач, } \\
\text { венчић од зелених из- } \\
\text { раштаја }\end{array}$ \\
\hline $\begin{array}{l}\text { knížka } \\
\text { 1. kniha, kniha vůbec } \\
\text { 2. sešit určený pro nějaké } \\
\text { záznamy, zprav. úřední } \\
\text { povahy, popř. jako prů- } \\
\text { kaz: vkladní, vojenská, } \\
\text { pracovní k. }\end{array}$ & $\begin{array}{l}\text { књижица, књига; } \\
\Delta \text { штедна, чековна, вој- } \\
\text { на, ђачка књижица (2) }\end{array}$ & $\begin{array}{l}\text { књижица } \\
\text { 1. дем. од књига. } \\
\text { 2. назив за разне доку- } \\
\text { менте у облику малих } \\
\text { заједно сашивених и } \\
\text { укоричених листова } \\
\text { с каквим текстом и } \\
\text { празним простором } \\
\text { за службене напомене } \\
\text { или белешке }\end{array}$ \\
\hline $\begin{array}{l}\text { kř̌žžek } \\
\text { 1. malý křriž } \\
\text { 2. podoba malého křižže v } \\
\text { růz. obměnách a v různém } \\
\text { užití; vyšívat křížkem }\end{array}$ & $\begin{array}{l}\text { 1. мали крст } \\
\text { 2. предмет налик на } \\
\text { крст } \\
\text {.. } \\
\text { 6. крстић (врста веза) (2) }\end{array}$ & $\begin{array}{l}\text { крсииић } \\
\text { дем. од крст }\end{array}$ \\
\hline
\end{tabular}

\footnotetext{
${ }^{8}$ Сматрамо да и у овом значењу функционише формални деминутив шеширић.
} 


\begin{tabular}{|c|c|c|}
\hline $\begin{array}{l}\text { kartáček } \\
\text { 1. zdrob. ke kartáč: k. na } \\
\text { zuby; přen. krátce při- } \\
\text { střižený knírek; } 2 \text {. zool. } \\
\text { první chlupatý článek } \\
\text { zadních noh včel, uzpů- } \\
\text { sobený k sběru pylu } \\
\text { 3. elektr. součást elek- } \\
\text { trického stroje, která při- } \\
\text { vádí n. odvádí proud }\end{array}$ & $\begin{array}{l}\text { 1. четкица } \\
\text { 2. прен. бркови поткре- } \\
\text { сани као четка } \\
\text { 3. зоол. маље, четкица } \\
\text { на првом чланку ноге } \\
\text { пчеле радилице; } \\
\Delta \text { четкица за зубе; ел. } \\
\text { контактна четкица }\end{array}$ & $\begin{array}{l}\text { чейкииа } \\
\text { дем. од четка; за зубе }\end{array}$ \\
\hline $\begin{array}{l}\text { korunka } \\
\text { 1. malá koruna } \\
\text { 2. exp. koruna jako pla- } \\
\text { tidlo } \\
\text { 3. rozvětvená listnatá } \\
\text { část stromu } \\
\text { 4. zool. péřová ozdoba na } \\
\text { hlavě někt. ptáků (např. } \\
\text { páva); bot. pakorunka } \\
\text { 5. anat. část zubu vyční- } \\
\text { vající z dásně; med. jejich } \\
\text { umělá náhrada }\end{array}$ & $\begin{array}{l}\text { 1. круница, круна } \\
\text { 2. експр. круна, динар } \\
\text { 3. круна, крошња (дрве- } \\
\text { та) } \\
\text { 4. бот. круница } \\
\text { 5. анат. круна (зуба); } \\
\text { мед. круница } \\
\text { 6. круна, ћуба }\end{array}$ & $\begin{array}{l}\text { круница } \\
\text { 1. а. дем. од круна; б. } \\
\text { врх, вршак чега } \\
\text { 2. бот. део цвета који } \\
\text { се састоји од одвојених } \\
\text { или сраслих цветних } \\
\text { листића, венчић }\end{array}$ \\
\hline $\begin{array}{l}\text { lístek } \\
\text { 1. zdrob k list rostliny } \\
\text { 2. papírový list malého } \\
\text { formátu } \\
\text { 3. pohlednice } \\
\text { 4. druh průkazu o ně- } \\
\text { čem svědčící, k něčemu } \\
\text { opravňující: volební } 1 . ; 1 \text {. } \\
\text { na vlak; l. do divadla } \\
\text { 5. tenký plátek: 1. stanio- } \\
\text { lu; l. šunky }\end{array}$ & $\begin{array}{l}\text { 1. листић, листак } \\
\text {.. } \\
\text { 3. дем. листић папира, } \\
\text { папирић (2) } \\
\text { 4. разгледница (4) } \\
\text { 5. карта, улазница (4) } \\
\text { 6. техн. фолија (5) }\end{array}$ & $\begin{array}{l}\text { листиић } \\
\text { дем. од лист. } \\
\text { Изр. гласачки листић }\end{array}$ \\
\hline
\end{tabular}




\begin{tabular}{|c|c|c|}
\hline $\begin{array}{l}\text { lopatka } \\
\text { 1. malá lopata } \\
\text { 2. věc lopatce podobná, } \\
\text { připomínající lopatku } \\
\text { tvarem n. též funkcí, zvl. } \\
\text { součást různých strojů a } \\
\text { zařízení } \\
\text { 3. plochá kost v horní } \\
\text { části zad }\end{array}$ & $\begin{array}{l}\text { 1. лопатица, мала лопата } \\
\text {.. } \\
\text { 3. анант. лопатица, } \\
\text { плећка (3) } \\
\text { 4. техн. лопатица, лопа- } \\
\text { та (2) }\end{array}$ & $\begin{array}{l}\text { лойайица } \\
\text { 1. дем. од лопата } \\
\text { 2. дашчица на воденич- } \\
\text { ном колу, на воденим } \\
\text { турбинама и сл. у коју } \\
\text { удара вода; прошире- } \\
\text { ни, пљоснати део раз- } \\
\text { них предмета (весла, } \\
\text { пропелера и др. } \\
\text { 3.анат. пљосната тро- } \\
\text { угласта кост за коју је } \\
\text { причвршћена рука код } \\
\text { човека или предња } \\
\text { нога код животиња }\end{array}$ \\
\hline $\begin{array}{l}\text { muška } \\
\text { 1. zdrob k moucha, malá, } \\
\text { drobná moucha } \\
\text { 2. odb. voj. část míridel } \\
\text { střelných zbraní } \\
\ldots \text {.. } \\
\text { 5. sport. slang. muší } \\
\text { váha: bojovat v mušce }\end{array}$ & $\begin{array}{l}\text { 1. мушица, мувица } \\
\text { 3. мушица на пушци (2) } \\
\text {.. } \\
\text { 5. мува, муха категорија }\end{array}$ & $\begin{array}{l}\text { мушищ, } \\
\text { 1. дем. од муха } \\
\text { 2. мн. зоол. инсекти, } \\
\text { кукци из реда двокри- } \\
\text { лаца } \\
\text { 3. војн. горњи део } \\
\text { предњег нишана стре- } \\
\text { љачког оружја }\end{array}$ \\
\hline $\begin{array}{l}\text { nožička } \\
\text { zdrob. k noha: dětská n.; } \\
\text { zaječí n.; kuch. smažené } \\
\text { telecí n-y; n-y u pera, n. } \\
\text { houby } \\
\text { nožka } \\
\text { 1. zdrob. k noha; n. hři- } \\
\text { bu } \\
\text { 2. co něčím nožku, třeba i } \\
\text { vzdáleně připomíná }\end{array}$ & $\begin{array}{l}\text { 1. ногица, ножица (де- } \\
\text { чја и сл.) } \\
\text { 2. нога, ножица (стола) }\end{array}$ & $\begin{array}{l}\text { нотичи, } a^{9} \\
\text { дем. и хип. од нога (обич- } \\
\text { но о нози мале деце) } \\
\text { ножица } \\
\text { 1. дем. и хип. од нога } \\
\text { 2. = ножац }\end{array}$ \\
\hline
\end{tabular}

${ }^{9}$ Као што видимо из дефиниције значења у РМС облик без палатализације се везује за део тела, док се онај са палатализацијом односи на део предмета. 


\begin{tabular}{|c|c|c|}
\hline $\begin{array}{l}\text { očko } \\
\text { 1. malé oko } \\
\text { 2. klička, smyčka, kroužek: } \\
\text { o. jehly, řetízku, na pun- } \\
\text { čoše, při háčkování } \\
\text { 3. věc, předmět n. jeho } \\
\text { část připomínající nějak } \\
\text { (zprav. kulatým tvarem) } \\
\text { malé oko: mastná o. na } \\
\text { polévce }\end{array}$ & $\begin{array}{l}\text { 1. окце, оканце } \\
\text { 2. петља, око } \\
\text { 3. кружић, тачка }{ }^{11}\end{array}$ & $\begin{array}{l}\text { окце } \\
\text { 1. дем. и хип. од око } \\
\text { 2. пчелина ћелија } \\
\text { 3. округао зачетак мла- } \\
\text { дице или цвета биљке, } \\
\text { пупољак који се прили- } \\
\text { ком калемљења умеће } \\
\text { под кору младице } \\
\text { 4. а. отвор на мрежи; б. } \\
\text { округлина у везу } \\
\text { оканце } \\
\text { 1. дем. од око } \\
\text { 2. пупољчић, окце (3) } \\
\text { 3. в. окце (4б). } \\
\text { очица } \\
\text { петља, окце (у плетиву, } \\
\text { на чарапи) }\end{array}$ \\
\hline $\begin{array}{l}\text { stromek } \\
\text { 1. zdrob. k strom } \\
\text { 2. vánoční s. } \\
\text { stromeček } \\
\text { zdrob. k stromek; vánoční s. }\end{array}$ & $\begin{array}{l}\text { stromek, stromeček } \\
\text { дрвце, мало, младо } \\
\text { дрво; } \Delta \text { божићно дрво, } \\
\text { дрвце, јелка }(2)^{12}\end{array}$ & $\begin{array}{l}\text { gрвие } \\
\text { 1. дем. од дрво, младо и } \\
\text { мало дрво } \\
\text { 2. ситно исцепано дрво } \\
\text { 3. Изр. божићно (бо- } \\
\text { жићње) јелка која се } \\
\text { кити за Божић }\end{array}$ \\
\hline $\begin{array}{l}\text { tabulka } \\
\text { 1. přehledně uspořáda- } \\
\text { ný a graficky členěný } \\
\text { seznam; mat. matema- } \\
\text { tické, logaritmické t.y } \\
\text { 2. dříve černá břidlico- } \\
\text { vá n. lepenková destička } \\
\text { užívaná k učení psaní } \\
\text { 3. malá tabule: t. na dve- } \\
\text { řích, orientační }\end{array}$ & $\begin{array}{l}\text { 1. таблица, табела; } \\
\text { 2. таблица (ђачка) } \\
\text { 3. мала табла, таблица, } \\
\text { плочица }\end{array}$ & 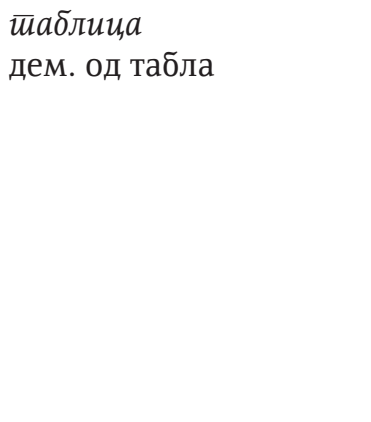 \\
\hline
\end{tabular}

${ }^{10}$ Сматрамо да би овде уз дате деминутиве могао бити и дериват окце, па чак и очиu, мада се у $P M C$ не дефинише као деминутив, али га И. Клајн наводи у вези са суфиксом -ица који је као деминутивни суфикс склон семантичким променама (2003 : 115).

${ }^{11}$ И овде би, по нашем мишљењу, могао стајати деминутив окце у значењу „предмет или његов део који обликом подсећа на мало око".

12 Формална значења првостепеног и другостепеног деминутива у чешком су иста, тако да су оба деривата у ЧСР наведена под истом одредницом. 


\begin{tabular}{|c|c|c|}
\hline $\begin{array}{l}\text { tyčinka } \\
\text { 1. zdrob. k tyč, k tyčka } \\
\text { malá tyčka n. (nejč.) něco } \\
\text { jí podobného protáhlým } \\
\text { tvarem } \\
2 . \text { bot. květní orgán } \\
\text { složený z nitky a z praš- } \\
\text { níkủ obsahujících pyl }\end{array}$ & $\begin{array}{l}\text { 1. штапић } \\
\text { 2. анат. штапић (/) } \\
\text { 3. бот. прашник (2) }\end{array}$ & $\begin{array}{l}\text { щй } а \bar{u} u ћ \\
\text { 1. дем. од штап } \\
\text { 2. мн. анат. врста ће- } \\
\text { лијица у } \\
\text { оку налик на штапиће }\end{array}$ \\
\hline $\begin{array}{l}\text { žabka } \\
\text { 1. zdrob. k žába; } \\
\text { 2. co žabku nějak připo- } \\
\text { míná; krejč. ozdobné zřa- } \\
\text { sení látky; elektr. ruční } \\
\text { svěradlo k napínání drátu } \\
\text { (napřr. při stavbě elektric- } \\
\text { kého vedení); hud. dolní } \\
\text { část smyčce se šroubem } \\
\text { k napínání žíní } \\
\text { 3. ob. hod oblázkem, aby } \\
\text { skákal a klouzal po vodní } \\
\text { hladině }\end{array}$ & $\begin{array}{l}\text { 1. жабица } \\
\text {... } \\
\text { 4. крој. жабица (украсни } \\
\text { набор на тканини) (2) } \\
\text { 5. муз. жабица (2) } \\
\Delta \text { разг. правити „жаби- } \\
\text { це” (3) }\end{array}$ & $\begin{array}{l}\text { жабица } \\
\text { 1. дем. од жаба } \\
\text { 2. врста ракете за ват- } \\
\text { ромет која скачући } \\
\text { (као жаба) праска } \\
\text { 3. а. украс на горњем } \\
\text { делу дршке пшитоља; } \\
\text { б. закачка, копча на ка- } \\
\text { ишу опанка } \\
\text { 4. мн. бацање пљосна- } \\
\text { тог каменчића по мир- } \\
\text { ној површини воде да } \\
\text { неколико пута одскочи. }\end{array}$ \\
\hline $\begin{array}{l}\text { žebř́íck } \\
\text { 1. řidč. a poněk. zast. } \\
\text { zdrob. k žebřík; } \\
\text { 2. stupnice pořadí osob } \\
\text { n. věcí podle výkonu, } \\
\text { hodnoty, významu ap. }\end{array}$ & $\begin{array}{l}\text { 1. лествице, мале лест- } \\
\text { ве } \\
2 . \text { спорт. ранг-листа } \\
\Delta \text { прен. друштвена лес- } \\
\text { твица (2) }\end{array}$ & $\begin{array}{l}\text { лесиивииа } \\
\text { 1. мн. дем. од лестве } \\
\text { 2. фиг. низ узастопних } \\
\text { ступњева чега (нпр. ка- } \\
\text { ријере) } \\
\text { 3. справа или посуда } \\
\text { за мерење, са уздужно } \\
\text { обележеним подеоци- } \\
\text { ма, скала }\end{array}$ \\
\hline $\begin{array}{l}\text { žebírko } \\
\text { 1. zdrob. k žebro } \\
\text { 2. potrav, kuch. maso na } \\
\text { žebrech a mezi žebry: } \\
\text { smažené ž.; ž. na rožni } \\
\text { 3. co něčím žebírko při- } \\
\text { pomíná }\end{array}$ & ребарце, ребро ${ }^{14}$ & $\begin{array}{l}\text { ребарие } \\
\text { дем. од ребро }\end{array}$ \\
\hline
\end{tabular}

${ }^{13}$ Деминутив се лексикализовао у облику једнине, док је за право деминутивно значење резервисан облик множине, као што је и мотивна реч - лесивве.

14 У ЧСР лексема није обрађена као полисемична реч. За значење под 2 , као врста јела, еквивалент би такође био деминутив, и то у облику множине ребариа. 
У овај тип спадају и еквиваленти у виду деминутива који су грађени од исте мотивне речи различитим суфиксима. Сваки од њих односи се на различите семеме једног полисемичног деминутива у чешком језику, те је у питању однос дивергенције.

\begin{tabular}{|c|c|c|}
\hline $\begin{array}{l}\text { člunek } \\
\text { 1. zdrob. k člun } \\
\text { 2. text. lodičkovité pouz- } \\
\text { dro s útkovou nití, které } \\
\text { se prohazuje osnovou: } \\
\text { tkalcovský č.; tech. zaří- } \\
\text { zení šicího stroje, které } \\
\text { vede spodní nit } \\
\text { 3. bot. část květu rostlin } \\
\text { motýlokvětých tvořená } \\
\text { dvěma spodními korun- } \\
\text { ními plátky }\end{array}$ & $\begin{array}{l}\text { мален чамац, чамчић, } \\
\text { чунић; барчица; } \\
\Delta \text { текст. чунак разбоја (2) }\end{array}$ & $\begin{array}{l}\text { чунак } \\
\text { дем. од чун } \\
\text { чунић } \\
\text { дем. од чун }\end{array}$ \\
\hline $\begin{array}{l}\text { jazýček } \\
\text { 1. zdrob k jazyk } \\
\text { 2. věc, předmět nebo jeho } \\
\text { část podobající se zprav. } \\
\text { úzkým dlouhým tvarem } \\
\text { jazýčku: j. zámku, u boty } \\
\text { 3. ukazatel kývající kolem } \\
\text { nějaké osy: j. vah }\end{array}$ & $\begin{array}{l}\text { 1. језичак, језичић, је- } \\
\text { зик; } \\
\text { 2. техн. језичак, стрели- } \\
\text { ца, игла } \\
\text { 3. муз. језичак }\end{array}$ & $\begin{array}{l}\text { језичак } \\
\text { 1. дем од језик (1) (пок- } \\
\text { ретљив, плоснат мишић } \\
\text { у усној шупљини чове- } \\
\text { ка и виших животиња } \\
\text { који служи као орган за } \\
\text { укус, за жвакање и гу- } \\
\text { тање хране ) и (2) (оно } \\
\text { што је својим обликом } \\
\text { или употребом слично } \\
\text { језику) } \\
\text { језичаи, } \\
\text { 1. дем од језик (1) и } \\
\text { (2)... } \\
\text { језичић } \\
\text { дем. од језик }\end{array}$ \\
\hline
\end{tabular}

15 Лексема чунак у РMC дефинисана је као деминутив, али по нашем мишљењу данас се тако не осећа, како су проценили и аутори ЧСР не употребивши је као преводни еквивалент за инваријантно значење чешке лексеме.

${ }^{16}$ Мада је у РМС ова лексема наведена као деминутивна, њу и све друге са суфиксом -ац И. Клајн повезује са семантичким померањем, док деминутивну функцију у данашњем језику сматра сведену на „gве-йри речи као брайаи, и креветиаи” (2003: 51). 


\begin{tabular}{|c|c|c|}
\hline $\begin{array}{l}\text { koník } \\
\text { 1. zdrob. ke kủň } \\
\text {.. } \\
\text { 3. dřevěná figura na kolo- } \\
\text { toči v podobě koně } \\
\text {.. } \\
\text { 6. ob. kobylka, saranče; } \\
\text { koníček } \\
\text { koníček } \\
\text { 1. zdrob. ke koník } \\
\text { 2. záliba } \\
\text {.. } \\
\text { 5. ob. kobylka n. saranče; } \\
\text { koník } \\
\text { 6. drobná mořská rybka } \\
\text { připomínající šachovou } \\
\text { figurku koně; zool. rod } \\
\text { Hippocampus }\end{array}$ & $\begin{array}{l}\text { 1. коњић, коњиц, коњче } \\
\text { 3. дрвени коњ на ринги- } \\
\text { шпилу } \\
6 . \text { разг. зелени скакавац, } \\
\text { коњић зелени }\end{array}$ & $\begin{array}{l}\text { коњић } \\
\text { 1. а. дем. од коњ; б. } \\
\text { шах. коњ } \\
\text { 2. а. коњиц (3б)... } \\
\text { 5. (обично мн.) дрвене } \\
\text { ноге или ногари на } \\
\text { којима леже даске } \\
\text { коњии, } \\
\text { 1. а. дем. од коњ... } \\
\text { 2. а. ослонац за струну } \\
\text { или } \\
\text { жицу на гудачким инс- } \\
\text { трументима, кобилица... } \\
\text { 3. зоол. а. мн. скакав- } \\
\text { ци... } \\
4 . \text { Изр. вилин (вилин- } \\
\text { ски, вилињи и сл.) } \\
\text { зоол. врста кукца, ин- } \\
\text { секта који живи поред } \\
\text { вода } \\
\text { коњче } \\
\text { дем. од коњ }\end{array}$ \\
\hline $\begin{array}{l}\text { mlýnek } \\
\text { 1. zdrob. k mlýn } \\
\text { 2. ruční přístroj na mletí: } \\
\text { na kávu, maso, mák } \\
\text { 3. stroj, zaházení připo- } \\
\text { mínající nějak (účelem } \\
\text { nebo podobou) mlýnek: } \\
\text { čistit obilí mlýnkem } \\
\text { - strojem na třídění a čis- } \\
\text { tění obilí; }\end{array}$ & $\begin{array}{l}\text { 1. мали млин, млинчић } \\
\text { 2. воденица, млинац, } \\
\text { ручни млин } \\
\text { 3. вејалица, тријер }\end{array}$ & $\begin{array}{l}\text { млинаи, } \\
\text { 1. мали ручни млин (за } \\
\text { млевење кафе) } \\
\text { 2. мн. кув. јело од теста } \\
\text { у облику плочастих ко- } \\
\text { мадића } \\
\text { печених и зачињених } \\
\text { машћу или маслом } \\
\text { млиниић } \\
\text { 1. дем. од млин } \\
\text { 2. в. млинац }\end{array}$ \\
\hline $\begin{array}{l}\text { polštářek } \\
\text { 1. zdrob k polštář } \\
\text { 2. věc vzhledem n. úče- } \\
\text { lem polštářek připomí- } \\
\text { nající; zool. polštářek } \\
\text { část chodidla hmyzu }\end{array}$ & $\begin{array}{l}\text { јастучић, јастуче } \\
\Delta \text { јастуче за игле, за пе- } \\
\text { чат (2) }\end{array}$ & 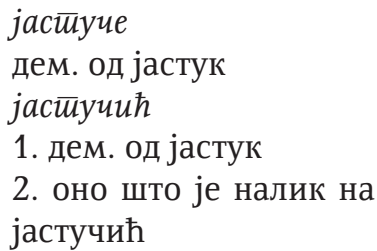 \\
\hline
\end{tabular}

17 У српком језику за ову врсту животиња користи се деминутивни дериват коњић или коњии, а наведено је у РМС. 


\begin{tabular}{|c|c|c|}
\hline $\begin{array}{l}\text { sloupek } \\
\text { 1. zdrob. k sloup } \\
\text { 2. novin. drobný, aktuál- } \\
\text { ní, vtipně psaný článek, } \\
\text { malý fejeton } \\
\text { 3. v ručních pracích } \\
\text { nahozené a provlečené } \\
\text { očko při háčkování }\end{array}$ & $\begin{array}{l}\text { 1. стубић } \\
\text { 2. стубац, колона } \\
\text { 3. новин. кратки фељ- } \\
\text { тон, чланак на једном } \\
\text { ступцу (2) } \\
\text { 4. стубић у кукичању } \\
\text { (3) }\end{array}$ & 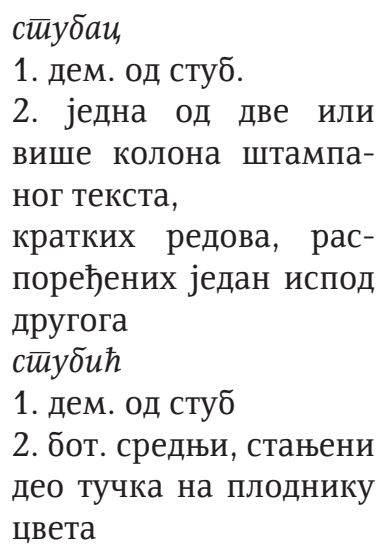 \\
\hline $\begin{array}{l}\text { zvonek } \\
\text { 1. zdrob. k zvon; z. jízd- } \\
\text { ního kola; elektrický z. u } \\
\text { dveří } \\
\text { 2. bylina se stř́davými } \\
\text { listy a s nálevkovitými n. } \\
\text { zvonkovitými modrými } \\
\text { n. bílými květy; bot. rod } \\
\text { Campanula } \\
\text { zvoneček } \\
\text { 1. zdrob. k zvonek } \\
\text { 2. lid. název růz. polních } \\
\text { květin, např. rožce, svět- } \\
\text { líku, náprstníku, konikle- } \\
\text { ce ap. }\end{array}$ & $\begin{array}{l}\text { 1. звонце, звончић } \\
\text { 2. дијал. бот. звонце, } \\
\text { звончић }\end{array}$ & $\begin{array}{l}\text { звонце } \\
\text { 1. дем. од звоно; мало } \\
\text { звоно } \\
\text { (нпр. електрично или } \\
\text { на бициклу); прапорац. } \\
2 . \text { бот. а. звончић } \\
(2 \mathrm{a}) . . \\
\text { 3вончић } \\
\text { 1. дем. од звоно } \\
\text { 3вонце } \\
\text { 1. дем. од звоно } \\
\text { 2. бот. а. назив за раз- } \\
\text { не врсте биљака зво- } \\
\text { настог цвета из рода } \\
\text { Сатрапиlа; б. мн. биљ- } \\
\text { на породица у коју спа- } \\
\text { дају те биљке }\end{array}$ \\
\hline
\end{tabular}


б. Формалном деминутиву у чешком језику еквивалент у српском језику је мотивна реч, еквивалентна са мотивном речју чешког деминутива.

\begin{tabular}{|c|c|c|}
\hline $\begin{array}{l}\text { branka } \\
\text { 1. zdrob. k brána } \\
\text { 2. sport. gól }\end{array}$ & $\begin{array}{l}\text { 1. дем. капиџик, вратан- } \\
\text { ца, врата, капија }{ }^{18} \\
\text { 2. спорт. врата, гол } \\
\text { 3. спорт. гол, погодак (2) }\end{array}$ & 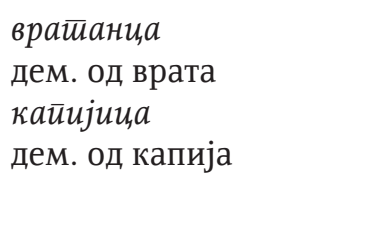 \\
\hline $\begin{array}{l}\text { kovadlinka } \\
\text { 1. zdrob ke kovadlina } \\
\text { 2. anat. kůstka v střed- } \\
\text { ním uchu }\end{array}$ & $\begin{array}{l}\text { 1. дем. мали наковањ } \\
\text { 2. анат. наковањ }\end{array}$ & $\begin{array}{l}\text { наковањиић } \\
\text { дем. од наковањ }\end{array}$ \\
\hline $\begin{array}{l}\text { mř́žča } \\
\text { 1. zdrob k mříž: ochran- } \\
\text { ná; m. okénka } \\
\text { 2. vzor z protínajících se } \\
\text { rovnoběžných čar } \\
\text { 3. věc připomínající mříž, } \\
\text { svým vzhledem, uspo- } \\
\text { řádáním ap.: krystalová, } \\
\text { optická m. }\end{array}$ & $\begin{array}{l}\text { дем. решеткица, решет- } \\
\text { ка; мрежица, мрежа; } \\
\Delta \text { кристална решетка (2) } \\
\text { заштитна решетка (1) }\end{array}$ & $\begin{array}{l}\text { решейкии,а } \\
\text { (није наведено) }^{19} \\
\text { мрежии, } \\
\text { дем. и хип. од мрежа; } \\
\text { фина мрежа од танких } \\
\text { нити }\end{array}$ \\
\hline $\begin{array}{l}\text { ocásek } \\
\text { 1. zdrob k ocas } \\
\text { 2. jídlo připravené ze zví- } \\
\text { řecí oháňky } \\
\text { 3. věc připomínající malý } \\
\text { ocas podobou n. umístěním }\end{array}$ & $\begin{array}{l}\text { 1. репић } \\
\text { 2. јело припремљено од } \\
\text { репа (телећег, свињс- } \\
\text { ког) } \\
\text { (3) (није наведено })^{20}\end{array}$ & $\begin{array}{l}\text { рейuћ } \\
\text { дем. од реп }\end{array}$ \\
\hline
\end{tabular}

${ }^{18}$ Могао би се навести и деминутив кайијиц,

${ }^{19}$ У $Р M C$ наведен је само дериват решеиии, (дем. од решетка).

${ }^{20}$ И у овом значењу могао би стајати деминутив рейић који се по нашем мишљењу користи у значењу „предмет који обликом или положајем подсећа на мали реп“. 


\begin{tabular}{|c|c|c|}
\hline $\begin{array}{l}\text { ouško } \\
\text { 1.expr. zdrob. k ucho } \\
\text { 2. něco tvarem, obrysem } \\
\text { n. jinak oušku n. jeho } \\
\text { části podobného: o. šál- } \\
\text { ku, o. jehly }\end{array}$ & $\begin{array}{l}\text { увце, ухо } \\
\Delta \text { дршка, ручица, ухо } \\
\text { земљаног лончића, } \\
\text { ушице на игли, иглене } \\
\text { уши }(2)^{21}\end{array}$ & $\begin{array}{l}\text { увиее } \\
\text { дем. од ухо } \\
\text { ушица (обично у мн.) } \\
\text { 1. метални део алатке } \\
\text { са отвором у који се } \\
\text { утиче држаље, копљача } \\
\text { и сл. } \\
\text { 2. отвор на игли кроз } \\
\text { који се удева конац } \\
\text { 3. омча, рупица уопште }\end{array}$ \\
\hline $\begin{array}{l}\text { prkénko, prkýnko } \\
\text { 1. zdrob k prkno } \\
\text { 2. dřevěná kuch. deska } \\
\text { na níž se krájí }\end{array}$ & $\begin{array}{l}\text { 1. дашчица, даска } \\
\text { (2) (није наведено) }{ }^{22}\end{array}$ & $\begin{array}{l}\text { gашиии,a } \\
\text { дем. од даска }\end{array}$ \\
\hline $\begin{array}{l}\text { slovíčko } \\
\text { 1. expr. zdrob k slovo } \\
\text { 2. jednotl. slovo při učení } \\
\text { cizímu j. } \\
\text { 3. expr. krátký rozho- } \\
\text { vor, krátká rozmluva n. } \\
\text { domluva }\end{array}$ & $\begin{array}{l}\text { 1. речца, реч } \\
\text { 2. реч (страног језика) } \\
\text { (3) (није наведено) })^{23}\end{array}$ & $\begin{array}{l}\text { речица } \\
\text { а. дем. и хип. од реч; б. } \\
\text { в. речца (2) } \\
\text { речц,а } \\
\text { 1. дем. и хип. од реч. } \\
\text { 2. грам. непроменљива } \\
\text { реч којом се исказује } \\
\text { лични } \\
\text { однос према ономе } \\
\text { што се реченицом са- } \\
\text { општава, } \\
\text { односно која служи за } \\
\text { истицање, појачавање, } \\
\text { одрицање, потврђивање } \\
\text { реченог и сл. }\end{array}$ \\
\hline
\end{tabular}

${ }^{21}$ Лексема ушии, у РMC није дефинисана као деминутив, али као такву, и са семантичким променама, наводи је И. Клајн (2003: 115).

22 У овом значењу користи се недеминутивна реч даска.

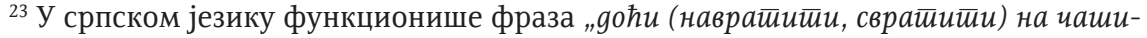
uу разі̄овора", како се наводи у Малом фразеолошком речнику Ђ. Оташевића (2007: 762), дакле такође је у питању деминутивна изведеница. 


\begin{tabular}{|c|c|c|}
\hline $\begin{array}{l}\text { vajičč } \\
\text { 1. zdrob. k vejce; vejce; } \\
\text { biol. zárodečná samičí } \\
\text { pohlavní buňka } \\
\text { 2. mravenčí kukla } \\
\text { 3. předmět připomínjící } \\
\text { tvarem vajićčko: nasypat } \\
\text { čaj do v-a }\end{array}$ & $\begin{array}{l}\text { 1. јајашце, јаје } \\
\text { 2. биол. јајна ћелија (1) } \\
\text { 3. мравља ларва (2) }\end{array}$ & $\begin{array}{l}\text { јајашие } \\
\text { дем. од јаје }\end{array}$ \\
\hline $\begin{array}{l}\text { víčko } \\
\text { 1. zdrob. k víko; techn. } \\
\text { krycí n. uzavírací sou- } \\
\text { částka u růz. přístrojů } \\
\text { 2. pohyblivý kožní útvar } \\
\text { chránící oko }\end{array}$ & $\begin{array}{l}\text { 1. поклопчић, мањи } \\
\text { поклопац } \\
\text { 2. анат. очни капак } \\
\text { 3. техн. поклопац, за- } \\
\text { клопац, капак (1) }\end{array}$ & $\begin{array}{l}\text { кайчић } \\
\text { дем од капак } \\
\bar{u} о к л о \bar{u} и ћ \\
\text { дем. од поклопац }\end{array}$ \\
\hline
\end{tabular}

в. Формалном деминутиву у чешком језику одговара формални деминутив у српском језику од неке друге мотивне речи. ${ }^{24}$

\begin{tabular}{|c|c|c|}
\hline $\begin{array}{l}\text { háček } \\
\text { 1. zdrob. k hák } \\
\text { 2. ryb. slang. udička } \\
\text { 3. nástroj k háčkování } \\
\text { 4. jeden ze dvou dílů šat- } \\
\text { ního spínadla, a to zpět } \\
\text { zahnutý } \\
\text { 5. zeměd. obilné stéblo s } \\
\text { klasem obráceným k zemi } \\
\text { 6. jaz. diakritické zna- } \\
\text { ménko nejč. označující } \\
\text { měkkost hlásky }\end{array}$ & $\begin{array}{l}\text { 1. кукица, кука } \\
\text { 2. сланг. удица } \\
\text { 3. кукица (за кукичање) } \\
\text { 4. мушка копча (за одело) } \\
\text { 5. квачица (дијакритич- } \\
\text { ки знак) (6) }\end{array}$ & $\begin{array}{l}\text { кукица } \\
\text { 1. дем. од кука } \\
\text { 2. фиг. препрека, } \\
\text { сметња, зачкољица. } \\
\text { 3. направа од дрвета или } \\
\text { метала са свинутим јед- } \\
\text { ним крајем, као сред- } \\
\text { ство за везење } \\
\text { квачии, }{ }^{24} \\
\text { 1. дем. од квака } \\
\text { 2. фиг. зачкољица, за- } \\
\text { качка, тешкоћа }\end{array}$ \\
\hline $\begin{array}{l}\text { kočárek } \\
\text { 1. zdrob ke kočár } \\
\text { 2. dětský k. - vozík k } \\
\text { vožení malých dětí }\end{array}$ & $\begin{array}{l}\text { 1. кочија, лака кола; } \\
\text { 2. дечија колица }\end{array}$ & $\begin{array}{l}\text { кочијии, } \\
\text { дем. од кочија } \\
\text { колиц, } \\
\text { 1. дем. од кола } \\
\text { 2. назив за разне мање } \\
\text { направе са једним, два, } \\
\text { три или четири точка, } \\
\text { које служе за превоз } \\
\text { материјала, деце, бо- } \\
\text { лесних лица и } \\
\text { др.: дечја , ручна }\end{array}$ \\
\hline
\end{tabular}

24 У $P M C$ није забележено значење „дијакритички знак“, али је свакако устаљен у том значењу, те га и ЧСР наводи. 


\begin{tabular}{|c|c|c|}
\hline $\begin{array}{l}\text { kolečko } \\
\text { 1. malé kolo } \\
\text { 2. pomn. kolečka, vozík } \\
\text { pod pluh ap. } \\
\text { 3. nářadí s jedním kolem } \\
\text { a držadly k ruční dopravě } \\
\text { písku apod. } \\
\text { 4. součástka různých } \\
\text { strojů: ozubené k. } \\
5 \text {. věc mající kruhový } \\
\text { tvar: k. salámu }\end{array}$ & $\begin{array}{l}\text { 1. точкић, точак } \\
\text { 2. пољопр. колечка, ко- } \\
\text { лечке } \\
\text { 3. колица } \\
\text { 4. круг, кружић, листић, } \\
\text { колут (5) }\end{array}$ & 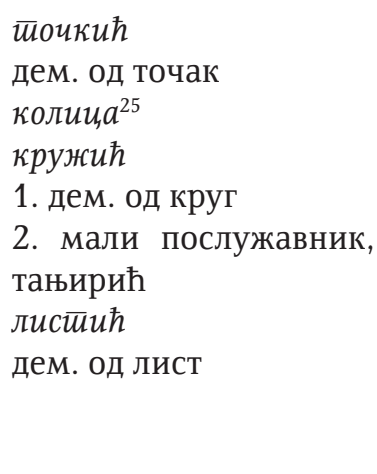 \\
\hline $\begin{array}{l}\text { mečík } \\
\text { 1. zdrob k meč } \\
\text { 2. techn. mečovitý pilník } \\
\text { ‥ } \\
\text { 4. okrasná bylina, gladiola }\end{array}$ & $\begin{array}{l}\text { 1. дем. кратак мач } \\
\text { 2. бот. гладиола }(4)^{26} \\
\text { 3. техн. двоклина тур- } \\
\text { пија (2) }\end{array}$ & $\begin{array}{l}\text { мачић } \\
\text { 1. дем. од мач. } \\
\text { 2. бот. в. сабљичица } \\
\text { сабљичии, } \\
\text { 1. дем. од сабљица. } \\
\text { 2. бот. биљка из пор. } \\
\text { перуника, гладиола }\end{array}$ \\
\hline $\begin{array}{l}\text { pérko, pírko } \\
\text { 1. (čast. pírko) zdrob. k } \\
\text { pero, péro; je lehká jako } \\
\text { p. málo váźí } \\
\text { 2. (zprav. jen pérko) } \\
\text { zdrob. k pero, péro stisk- } \\
\text { nout p. aparátu; p. u } \\
\text { hodinek; spravit p. dét- } \\
\text { ského autíčka }\end{array}$ & $\begin{array}{l}\text { 1. перце, перо (птичје) } \\
\text { 2. опружица, федерчић }\end{array}$ & 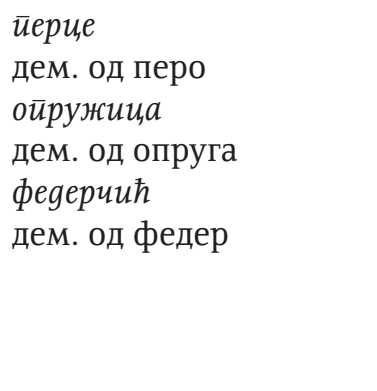 \\
\hline $\begin{array}{l}\text { školka } \\
\text { 1. zdrob. k škola } \\
\text { 2. hovor. mateřská škola } \\
\text { 3. pozemek, na kt. se } \\
\text { pěstují sazenice mladých } \\
\text { stromků; } \\
\text { 4. dětská hra, sestava cviků } \\
\text { se švihadlem, míčem ap. }\end{array}$ & $\begin{array}{l}\text { (1) (није наведено) })^{27} \\
\text { 1. разг. дечији вртић (2) } \\
\text { 2. шум. расадник (3) } \\
\text { (4) (није наведено })^{28}\end{array}$ & 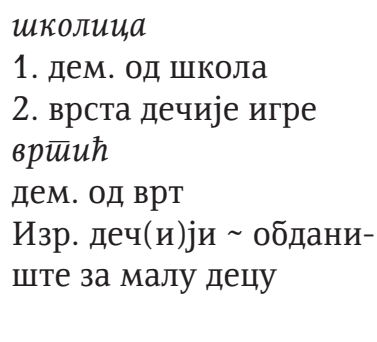 \\
\hline
\end{tabular}

${ }^{25}$ Вид. под kočárek.

${ }^{26}$ Могла би бити наведена и лексема сабљиนии, а, а у $P M C$ се чак и деминутив мачић односи на исту биљку.

27 У ЧСР није наведено инваријантно, право деминутивно значење.

${ }^{28}$ И у српском језику деминутив означава дечију игру, а ради се о другачијој игри од оне коју означава еквивалент у чешком језику. 
2930

\begin{tabular}{|c|c|c|}
\hline $\begin{array}{l}\text { štítek } \\
\text { 1. zdrob. k štít } \\
\text { 2. tabulka, destička, } \\
\text { nálepka n. jen čarami } \\
\text { vymezená ploška s ozna- } \\
\text { čením věci n. s něj. nápi- } \\
\text { sem; techn. děrný š. }\end{array}$ & $\begin{array}{l}\text { (1) (није наведено) }{ }^{29} \\
\text { 1. плочица, таблица (с } \\
\text { натписом) (2) } \\
\text { 2. етикета, налепница, } \\
\text { цедуља } \\
\Delta \text { бушена картица (2) }\end{array}$ & 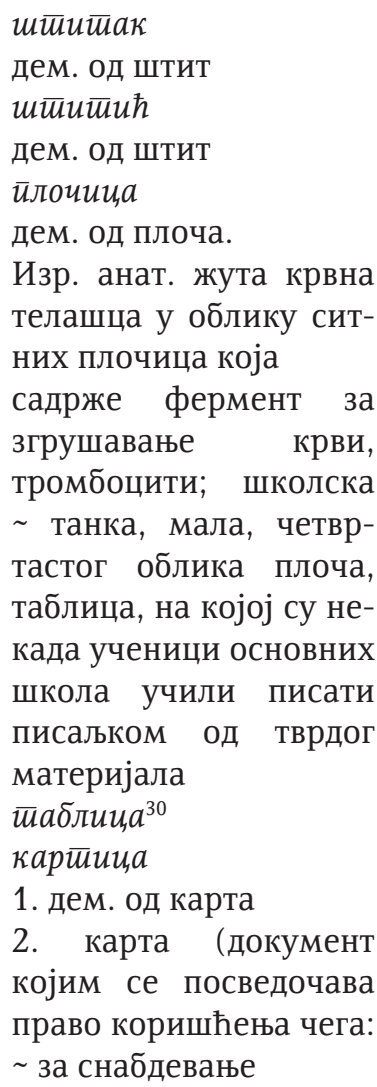 \\
\hline $\begin{array}{l}\text { trubka } \\
\text { 1. zdrob. k trouba } \\
\text { 2. žestový hud. nástroj } \\
\text { 3. trubice, rourka } \\
\text { 4. co připomíná tvarem } \\
\text { troubku: t.y svinutého } \\
\text { papíru }\end{array}$ & $\begin{array}{l}\text { 1. муз. труба, трубица (2) } \\
\text { 2. цев, цевчица ( } 3) \\
\text { 3. ролна }\end{array}$ & 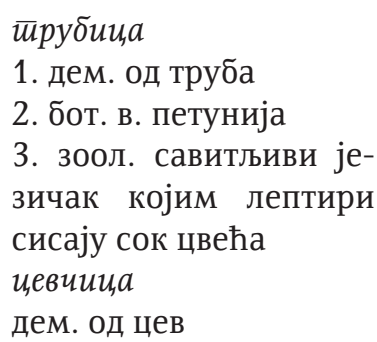 \\
\hline
\end{tabular}

29 Вид. нап. 27.

${ }^{30}$ Вид. под tabulka. 
г. Преводни еквивалент у српском језику није повезан ни са деминутивном изведеницом нити са њеном мотивном речи у чешком језику, нити са деминуцијом уопште. ${ }^{31}$

\begin{tabular}{|c|c|c|}
\hline $\begin{array}{l}\text { copánek } \\
\text { 1. zdrob k copan } \\
\text { 2. druh vzoru v pletivu }\end{array}$ & $\begin{array}{l}\text { 1. мала витица, кикица, } \\
\text { плетеница } \\
\text { 2. плетеница (шара у } \\
\text { плетењу) }\end{array}$ & $\begin{array}{l}\text { кикии,а } \\
\text { дем. од кика }\end{array}$ \\
\hline $\begin{array}{l}\text { kolík } \\
\text { 1. zdrob. ke kůl } \\
\text { 2. kolíček: k. na prádlo; } \\
\text { k-y u houslí, u basy } \\
\text { 3. co tvarem připomíná } \\
\text { malý tenký kůl: sport. } \\
\text { štafetový k. štafeta; } \\
\text { tech. spojovací, válcovitá } \\
\text { strojní součást: válcový, } \\
\text { kuželový k. } \\
\text { kolíček } \\
\text { zdrob. ke kolík: k. v hrá- } \\
\text { bích; k-y na věšení prádla; } \\
\text { k. u houslí, u basy součást } \\
\text { zařízení k měnění napětí } \\
\text { strun; řem. dřevěný nýtek } \\
\text { k upevňování podešví }\end{array}$ & $\begin{array}{l}\text { 1. кочић, клин } \\
\text { 2. штипаљка за рубље } \\
\text { 3. муз. чивија (2) } \\
\text { 4. техн. заворањ (3) } \\
\end{array}$ & $\begin{array}{l}\text { клинчић } \\
\text { дем. од клинац } \\
\text { кочић } \\
\text { дем. од колац }\end{array}$ \\
\hline $\begin{array}{l}\text { pěšinka, } \\
\text { 1. zdrob k pěšina } \\
\text { 2. úzká mezera mezi roz- } \\
\text { čísnutými vlasy }\end{array}$ & $\begin{array}{l}\text { 1. пешачка стазица, пу- } \\
\text { тељак } \\
\text { 2. раздељак }{ }^{31}\end{array}$ & $\begin{array}{l}\text { стиазии, } \\
\text { 1. дем. од стаза } \\
\text { 2. стаза (раздељак у коси) }\end{array}$ \\
\hline
\end{tabular}

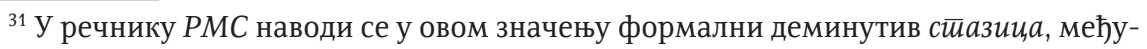
тим по нашем језичком осећању, његова употреба није фреквентна. 
323334

\begin{tabular}{|c|c|c|}
\hline $\begin{array}{l}\text { ramínko } \\
\text { 1. zdrob. k rameno; } \\
\text { potrav. vepřové maso od } \\
\text { ramenního kloubu } \\
\text { 2. pomůcka k zavěšení oděvu } \\
\text { 3. úzký pásek látky, často } \\
\text { stužka, držící na ramenou } \\
\text { zejm. dámské prádlo }\end{array}$ & $\begin{array}{l}\text { 1. дем. ручица } 32 \\
\text { 2. вешалица за одело } \\
\text { 3. нараменица, бретела } \\
\Delta \text { свињска плећка (1) }\end{array}$ & $\begin{array}{l}\text { рамени,е } \\
\text { дем. и хип. од раме } \\
\text { рамешие } \\
\text { дем. и хип. од раме }\end{array}$ \\
\hline $\begin{array}{l}\text { ručička } \\
\text { 1. zdrob. k ruka } \\
\text { 2. ukazatel času; techn. } \\
\text { ukazatel nadměrné hod- } \\
\text { noty na stupnici růz. } \\
\text { měřicích přístrojů, npř } \\
\text { barometru }\end{array}$ & $\begin{array}{l}\text { 1. ручица, рукица } \\
\text { 2. сказаљка на сату и } \\
\text { сл. }\end{array}$ & $\begin{array}{l}\text { рукuи, } a^{33} \\
\text { дем. и хип. од рука, ру- } \\
\text { чица } \\
\text { ручиц, } \\
\text { 1. дем. и хип. од рука } \\
2 . \quad \text { а. део предме- } \\
\text { та (пољопривредног, } \\
\text { ручног алата, посуђа, } \\
\text { оружја и сл.) који се } \\
\text { држи или хвата руком, } \\
\text { држак, дршка: плуга, } \\
\sim \text { ножа, лонца, за гас }\end{array}$ \\
\hline $\begin{array}{l}\text { sprška } \\
\text { 1. menší, krátký dešt; pře- } \\
\text { háňka, přeprška, prška } \\
\text { 2. shluk, proud pada- } \\
\text { jících krůpějí n. vůbec } \\
\text { drobných částeček něče- } \\
\text { ho; jad. fyz. radioaktivní } \\
\text { s-y - částice vzniklé při } \\
\text { srážce vysoké energie }\end{array}$ & $\begin{array}{l}\text { краткотрајна } \\
\text { краткотрајан } \\
(1)^{34} \\
\Delta \quad \text { пљушуакак } \\
\text { зрачења }(2)\end{array}$ & $\begin{array}{l}\text { кишиц, } \\
\text { дем. од киша }\end{array}$ \\
\hline
\end{tabular}

На основу претходног можемо извући закључке који се тичу процеса лексикализације деминутивних деривата у сваком од језика понаособ, као и оних који се односе на чешки и српски језик у поређењу.

32 Деминутив у чешком језику изведен је од мотивне речи rameno чије је инваријантно значење „с̌ást horní končetiny pripojující se kloubem a kostí k trupu” - раме, а као варијанта наводи се под бројем 2 „lidská horní končetina $n$. její část od lokte po lopatku n. po prsty; paže" - рука. Стога би код деминутивне изведенице као преводни еквивалент требало такође да стоји раменце, рамешце.

${ }_{3} 3$ За деминутивне облике рукииа/руиии, важи речено у напомени 9.

${ }^{34}$ Могао би бити наведен и деминутив кищииа. 
Што се тиче творбених средстава, у нашој грађи лексикализоване деминутивне изведенице грађене су у чешком језику примарним и секундарним суфиксима -ek, -eček, -ík, -íček, -ka, -ička, -inka, -ko, -ečko, -íčko. У српском језику преводни еквиваленти изведени су примарним и секундарним суфиксима -ић, -чић, -ица, -чица, -це, -анце, -че, -ак, -ац, -иц, с тим што треба нагласити да су последња три суфикса данас непродуктивна у функцији деминуције и да се изведенице не осећају као умањенице. ${ }^{35}$ Дакако, $P M C$ ове деривате наводи као деминутивне у инваријантном значењу.

Процес лексикализације деминутива у чешком језику најчешће обухвата првостепене деминутиве, док другостепене изведенице задржавају право деминутивно и/или хипокористично значење, нпр:

lístek 1. zdrob. k list rostliny; 2. zdrob. k papírový list; 3. pohlednice; 4. druh průkazu; lísteček zdrob. k lístek (1).

zvonek 1. zdrob. k zvon: z. jízdního kola; elektrický z.; z.u dveří; 2. bylina - Campanula;

zvoneček zdrob. k zvonek (1).

Обрнута ситуација је много ређа и већином првостепени деминутиви поред правог деминутивног значења имају и специјализацију, као нпр:

tyčka zdrob. k tyč; menší tyč; nastřelit tyčku (v kopané) svislou část branky; les. tyčky užitkové døíví mající u silnìjšího konce ménì než $7 \mathrm{~cm}$ v prùmìru; sport. slang. skok o tyèi;

tyčinka 1. zdrob. k tyčka; 2 . něco tyčce podobného tvarem; kuch slané; anat. zraková buňka sítnice umožňující vidění za šera; 3. bot. květní orgán složený z nitky a z prašníků.

Ретке су и ситуације лексикализације деминутива оба степена код којих постоји једно или више синонимичних значења, као у примеру:

koník 1. zdrob. ke kůň; 2. dřevěná figura na kolotoči v podobě koně... 6. ob. kobylka saranče; koníček;

koníček 1. zdrob ke kůň; 2. záliba; 3. dřevěná figura na kolotoči v podobě koně... 5. ob. kobylka (2) n. saranče; koník.

У српском језику другостепена деривација деминутива је слабо продуктивна, а њихова употреба везана углавном за експресивну сферу, али и ту се наилази на случајеве лексикализације изведенице на само једном степену, било на првом или другом, или пак на оба степена са већом или мањом појавом синонимије:

${ }^{35}$ О томе вид. монографију о творби речи И. Клајна (2003: 26, 51, 113). 
gрвие 1. дем. од дрво, младо и мало дрво; 2. ситно исцепано дрво; 3. Изр. божићно (божићње) јелка;

gрвешие дем. од дрвце.

сабљииа дем. и хип. од сабља;

сабљичии, 1. дем. од сабљица; 2. бот. биљка из пор. перуника, гладиола.

окце 1. дем. и хип. од око; 2. пчелина ћелија; 3. округао зачетак младице или цвета биљке, пупољак који се приликом калемљења умеће под кору младице; 4. а. отвор на мрежи б. округлина у везу;

оканце 1. дем. од око; 2. пупољчић, окце (3); 3. в. окце (4б).

Деминутиви у чешком језику грађени од исте мотивне речи различитим суфиксима, на истом степену, представљају синониме на основу инваријантног значења, али се разилазе присуством или одсуством секундарних значења, тако да је само један од деривата развио лексикализацију, нпр:

hvězdička, hvězdinka 1. zdrob. k hvězda; 2. jen hvězdička - znaménko v písmě.

У српском језику такође постоји овакав однос:

језичак 1. дем од језик (1) (покретљив, плоснат мишић у усној шупљини човека и виших животиња који служи као орган за укус, за жвакање и гутање хране ) и (2) (оно што је својим обликом или употребом слично језику) - језичић дем. од језик.

У чешком језику иста је ситуација и код фонетских варијаната истог деминутива, када се један облик лексикализовао, док други задржава само право деминутивно значење, као што је у примеру:

pérko, pírko 1. (čast. pírko) zdrob. k pero, péro; je lehká jako p. málo váží; 2. (zprav. jen pérko) zdrob. k pero, péro stisknout p. aparátu; p. u hodinek; spravit p. dětského autíčka.

У српском језику овакав случај представљају изведенице са алтернацијом:

рукии, дем. и хип. од рука, ручица - руиища 1. дем. и хип. од рука, 2. а. део предмета

ноіиица дем. и хип. од нога обично о нози мале деце - ножица 1. дем. и хип. од нога; 2. = ножац.

Можемо закључити да и у српском и у чешком језику долази до сличних процеса метафоричних и метонимијских преноса значења са правог деминутивног на лексикализовано значење, као што би се и очекивало међу сродним језицима, те да су случајеви формалне еквиваленције заступљени у знатном броју. 
Што се тиче лексикографске обраде формалних деминутива, једнојезични речници чешког и српског језика знатно се разликују у приступу овим језичким једницама. Наше је мишљење да су оне у речнику SSJČ обрађене детаљно и у већини случајева прецизно дефинисане, у $P M C$ су, чини нам се, лексикализована значења знатно слабије обухваћена, често наиме недостаје обрада деминутива као полисемичне лексеме, или недостају поједина, по нашем мишљењу фреквентна лексикализована или бар специјализована значења. Сматрамо такође да су аутори ЧСР презентацији и обради лексикализованих значења деминутива приступили детаљно, да је преводна семантизација прецизна и добро промишљена, те да речник у целини приказује завидан фонд ових лексема како у чешком, тако и у српском језику.

Надамо се да и наше истраживање може да потврди несумњиву међусобну повезаност конфронтативних истраживања словенских језика и двојезичне словенске лексикографије и да показује да се обе области не само прожимају, већ да се њихова достигнућа могу применити и на анализу и обраду језичких јединица у сваком од ових језика понаособ.

\section{Цитирана литература}

Бечева, Ничка. „О дублетности код деминутива и аугментатива у савременом српском језику". Научни састанак слависта у Вукове дане 29/1, 2000: 197-202.

Драгићевић, Рајна. „Творбени и семантички статус једног значења именица тпа ручица". Српски језик 13/1-2, 2008: 203-213.

Грицкат, Ирена. „О неким особеностима деминуције”. Јужнословенски филолог 51, 1995: 1-30.

Јанић, Александра. „Критеријуми за идентификацију лексикализованих деминутива у српскоме језику". Годишњак за српски језик XXV/12, 2012: 79-88.

Јанић, Александра. „Лексикализација именичких деминутива у српскоме језику". Philologia mediana V/5, 2013: 367-380.

Клајн, Иван. Творба речи у савременом српском језику II. Суфиксација и конверзија. Београд, 2003.

Легурска, Палмира, Бечева, Ничка. „Проблеми на семантиката на деминутивите в руския, срббкия и българския език и представянето и в двуезичен речник". Јужнословенски филолог 56, 1/2, 2000: 577-588.

Матијашевић, Јелка. Типови међујезичких еквивалената (на материјалу руских и српских именичких деминутива. [У:] Драгићевић, Р. Творба речи и њени ресурси у словенским језицима. Београд: Филолошки факултет, 2012, 653-660.

Радић, Првослав. „О деривационом аспекту речничког богаћења: нормативистички приступ". Језик данас 1, 1997: 22-24.

Станковић, Богољуб. Лексикографски огледи. Београд, 1999. 
Bakardžieva, Ginka. „O pastech a pastičkách deminutiv”. Bohemistyka 7, 3, 2007: 207-219.

Hladká, Zdeňka. „Uplatnění formální demunuce v tvorbě lidových jmen rostlin”. Sborník prací Filozofické fakulty brněnské univerzity, A, Řada jazykovědná, 47, 1998: 107-112.

Karlík, Petr, Nekula, Marek, Pleskalová, Jana (eds.) Nový encyklopedický slovník češtiny. Praha, 2016.

Peco, Asim, Stanojčić, Živojin. (eds.) Srpskohrvatski jezik. Enciklopedijski leksikon Mozaik znanja. Beograd, 1972.

Šmilauer, Vladimír. Novočeské tvoření slov. Praha, 1971.

Štícha František a kol. Akademická gramatika spisovné češtiny. Praha, 2013.

\section{Извори}

Качаник, Емилија et al. Чешко-српски речник I, II. Београд, 2001.

Стевановић, Михајло et al. (eds.) Речник српскохрватскога књижевног језика I-VI. Нови Сад - Загреб, 1967-1976.

Оташевић, Ђорђе. Мали фразеолошки речник српског језика, Београд 2007.

Havránek, B., Bělič, J., Helcl, M., Jedlička, A. (eds.) Slovník spisovného jazyka českého I-IV. Praha 1960-1971.

Katarina Mitrićević-Štepanek

\section{LEXICALIZED DIMINUTIVES IN THE CZECH LANGUAGE AND THEIR LEXICOGRAPHICAL EQUIVALENTS IN BILINGUAL CZECH-SERBIAN DICTIONARY}

\section{Summary}

The paper deals with diminutive derivatives with lexicalized meaning. The form and semantics of these derivatives in the Czech language and their lexicographical equivalents in the Serbian language are analysed, based on entries in monolingual dictionaries of Czech and Serbian and bilingual Czech-Serbian dictionary. It is concluded that contrastive analysis and bilingual lexicography of Czech and Serbian language are not only interconnected, but also applicable to the analysis and lexicographical treatment in each of these languages separately.

Keywords: lexicalized diminutives, lexicalization, Czech language, Serbian language, equivalence, bilingual dictionary, lexicographical treatment of entries 